\title{
Options for Land Conservation Practices Based on Land Uses in Kungkai Watershed, Bengkulu, Sumatera, Indonesia
}

\author{
Muhammad Faiz Barchia
}

\begin{abstract}
This research aims to determine options for land conservation practices based on land uses and functions in Kungkai watershed, Bengkulu, Sumatera, Indonesia. The research was conducted from March to May, 2013 in the Kungkai watershed geographically lying on between $102^{0} 22^{\prime} 25^{\prime \prime}$ - 102 36'15" Lat., and on $3^{0} 48{ }^{\prime} 25$ " - 4 $4^{0} 7^{\prime} 37^{\prime}$ " Long. This area is involved of Seluma District, Bengkulu Province, Sumatera, Indonesia, with run-off along $45 \mathrm{~km}$ to Indian Ocean, covering of 33,134.04 ha.

The Kungkai watershed currently is under environmentally pressures in which $40 \%$ more categorizing poor conditions. The Semidang Bukit Kabu wildlife hunting area covering $2,275.35$ Ha, or $6.88 \%$ of the Kungkai watershed almost all under poor conditions. This wildlife hunting area must be conducted reforestation. People living, and their activities on the wildlife hunting area have to re-settle. The Bukit Daun and Bukit Sanggul have any opportunities as an area of social forestry introducing agro-forestry cultivation models with planting of multi-purposes tree species. All areas of agriculture cultivation on the watershed need land conservation tillage and management with environmentally sounding for their sustainability productivities. Options for land management practices using cover crops, minimum tillage, till bench terrace implementation needed for sustainable agriculture on the Kungkai watershed.
\end{abstract}

Index Terms-Kungkai Watershed, Land Degradation, Land Conservation Practices.

\section{INTRODUCTION}

Watershed plays important rules on ecosystem sustainability interactions within, and surrounding of its, through of human life [1]. In watershed ecosystems, several land uses and functions, geo-morphological formations, plants and animals, physical infrastructures, social facilities, and human activities interact each other and together to form ecosystem balancing [2]. When watershed underwent degradation, all components to form and depending on the watershed, in short, are suffered [3]. Last decades, mostly watersheds in Indonesia have facing with pressures by human activities, down functions for whole components of its. And today, 62 unit of them have been undergoing deplete its functions [4]. Watershed degradation have been accelerated by increasing exploitation of natural resources because of doubling population, pushing economic growth, split

Manuscript received March 12, 2015; revised June 11, 2015.

Muhammad Faiz Barchia is with the Faculty of Agriculture, University of Bengkulu, Bengkulu, Indonesia. (E-mail: faiz_barchia@yahoo.com). understanding of watershed management and practices [5].

Landforms and behavior of watersheds in Bengkulu are different characteristics with other areas in which distance between upstream and downstream relatively short, tens kilometers, and narrow boundaries [6]. Upstream of the watersheds lies on Bukit Barisan hilly ranges, and downstream of those are run-off to Indian Ocean. Short distances between upstream and downstream form steeply landform and short drainage systems on the watersheds, causing rain water fast release to outlet in Indian Ocean.

Some watersheds in Bengkulu, Kungkai watershed of ones, have been depleted their natural and social functions. Agriculture land and forest areas on the Kungkai, on the upstream also currently, under intensive cultivation practices by both traditional farmers and coming from out the area. The cultivation practices on the Kungkai have not considered good agricultural practices, and un-integrated planning for whole functions of ecosystem components of the Kungkai watershed. Future, integrated management planning and technical conservation practices should be involved in understanding the Kungkai; therefore, optimally empowerment of natural resources on the Kungkai could harvested in peak of productivities and in long run environmental sustainability values.

\section{METHODS}

Kungkai watershed lies on $102^{0} 22^{\prime} 25^{\prime \prime}$ - $102^{0} 36^{\prime} 15^{\prime \prime}$ Lat., and on $3^{0} 48^{\prime} 25^{\prime \prime}-4^{0} 7$ '37' Long. The Kungkai is on District of Seluma, Bengkulu Province, Sumatera, Indonesia with length of $45 \mathrm{~km}$, and wide areas of 33,134.04 ha. Research location showed in Fig. 1 a) and Fig. 1 b).

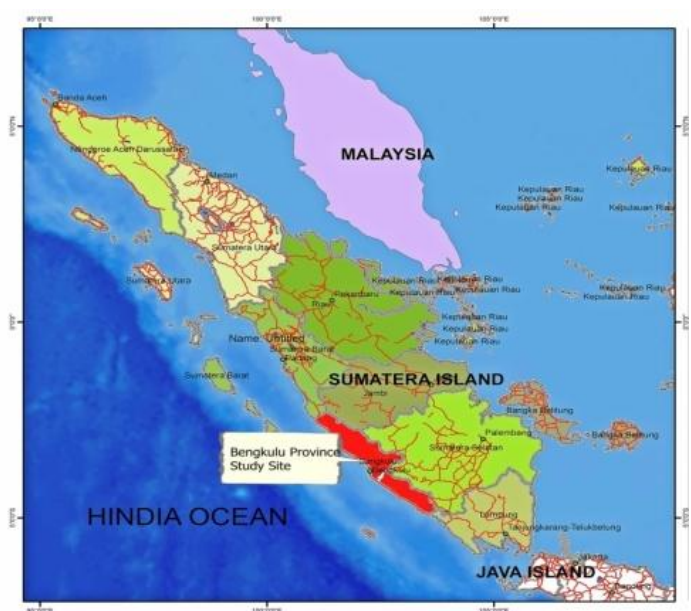

Fig. 1 a). Map of Bengkulu Province, Sumatera, Indonesia. 
TABLE I: WidE AREA OF DEgRADED LAND ON KUNGKAI WATERSHED, BENGKULU, SUMATERA, INDONESIA [12]

\begin{tabular}{|c|c|c|c|c|c|c|c|}
\hline \multirow[b]{2}{*}{ Degraded Level } & \multicolumn{4}{|c|}{ Wide Area of Forests (Ha) } & \multirow[b]{2}{*}{$\begin{array}{c}\text { Agriculture } \\
\text { Area }\end{array}$} & \multirow[b]{2}{*}{ Total } & \multirow[b]{2}{*}{$\%$} \\
\hline & $\begin{array}{c}\text { Bukit } \\
\text { Daun } \\
\text { P.F. }\end{array}$ & $\begin{array}{c}\text { Bukit } \\
\text { Sanggul } \\
\text { P.F }\end{array}$ & $\begin{array}{l}\text { Semidang Bukit } \\
\text { Baku } \\
\text { Wildlife Hunting } \\
\text { Area }\end{array}$ & $\begin{array}{c}\text { Enclave } \\
\text { Padang } \\
\text { Capo }\end{array}$ & & & \\
\hline Potential Degraded & 22,34 & $2,219.2$ & 188.68 & - & - & $2,430.32$ & 7.35 \\
\hline Light Degraded & 2.149 & 338.56 & 1621.39 & $1,381.51$ & $13,536.22$ & $16,879.83$ & 51.03 \\
\hline Degraded & - & 47.37 & 465.28 & $3,348.68$ & $9,257.47$ & $13,118.79$ & 39.66 \\
\hline Poor Degraded & - & - & - & 173.08 & 475,472 & 648.552 & 1.96 \\
\hline$\Sigma$ & 24.49 & $2,605.22$ & $2,275.35$ & $4,903.27$ & $23,269.16$ & $33,077.494$ & 100.00 \\
\hline
\end{tabular}

TABLE II: Options FOR LAND CONSERVATION AND MANAGEMENT PRACTICES ON FOREST PROTECTED AREA OF BUKIT DAUN AND BUKIT SANGGUL, KUNGKAI WATERSHED, BENGKULU, SUMATERA, INDONESIA

\begin{tabular}{|c|c|c|c|c|c|}
\hline \multirow{2}{*}{ Degraded Level } & \multicolumn{2}{|c|}{ Wide Protected Forest Area (Ha) } & \multirow{2}{*}{$\begin{array}{l}\text { Total Area } \\
\text { (Ha) }\end{array}$} & \multirow{2}{*}{$\%$} & \multirow{2}{*}{$\begin{array}{c}\text { Options for } \\
\text { Conservation Practices }\end{array}$} \\
\hline & Bukit Daun & Bukit Sanggul & & & \\
\hline Potential Degraded & 22.34 & $2,219.2$ & $2,214.54$ & 6.78 & Social Forestry \\
\hline Light Degraded & 2.149 & 338.56 & 340.71 & 1.03 & Social Forestry \\
\hline Degraded & 0 & 47.37 & 47.37 & 0.14 & Social Forestry \\
\hline$\sum$ & 24.489 & $2,605.22$ & 2.629 .62 & 7.95 & Social Forestry \\
\hline
\end{tabular}

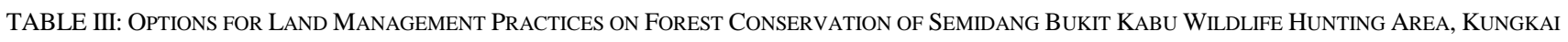
WATERSHED, BENGKULU

\begin{tabular}{|l|c|c|c|}
\hline \multicolumn{1}{|c|}{ Degraded Level } & $\begin{array}{c}\text { Wide Forest of Semidang } \\
\text { Bukit Kabu Wildlife Hunting } \\
\text { Area }\end{array}$ & $\%$ & $\begin{array}{c}\text { Options for Conservation } \\
\text { Practices }\end{array}$ \\
\hline Potential Degraded & 188.68 & 0.57 & Reforestation \\
\hline Slight Degraded & $1,621.39$ & 4.90 & Reforestation \\
\hline Degraded & 465.28 & 1.407 & Reforestation \\
\hline$\sum$ & $2,275.35$ & 6.88 & Reforestation \\
\hline
\end{tabular}

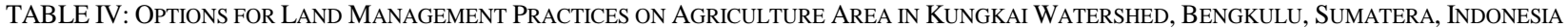

\begin{tabular}{|l|c|c|c|c|c|}
\hline \multirow{2}{*}{ Degraded Level } & $\begin{array}{c}\text { Agric. Area of } \\
\text { Enclave Padang } \\
\text { Capo } \\
\text { (Ha) }\end{array}$ & $\begin{array}{c}\text { Agric. Area of } \\
\text { Traditional Villagers } \\
\text { (Ha) }\end{array}$ & $\begin{array}{c}\text { Total } \\
\text { (Ha) }\end{array}$ & $\begin{array}{c}\text { Options for Conservation } \\
\text { Practices }\end{array}$ & $\begin{array}{c}\text { Minimum Tillage and cover crops } \\
\text { Slight Degraded }\end{array}$ \\
\hline Degraded & $3,381.51$ & $13,536.22$ & $14,917.73$ & 45.10 \\
\hline Poor Degraded & 173.08 & $9,257.47$ & $12,606.15$ & 38.11 & Credit terrace and cover crops. \\
\hline$\Sigma$ & $4,903.27$ & 475,472 & 648.55 & 1.96 & Bench terrace and cover crops \\
\hline
\end{tabular}

This research related to previous research conducted, and this research concern with options of land conservation practices based on land management and environmental values. Analysis degraded land conditions written functions over the area observed in which the land on Kungkai was under degraded condition written by [7] based on Rules of Directorate General for Land Rehabilitation and Social Forestry, Ministry of Forestry, Republic of Indonesia No. SK.167/V-SET/2004 [8] shown in Table I.

Secondary data collected related with this research were validated through ground check in some location in field to perform the data. Options for land management practices were different between agriculture area [9] and forestry area [10], and other related references.
Figuring result for options of land conservation and management practices based on land uses and functions needed Map of Indonesia Landforms and digital ALOS photos from Badan Informasi Geospasial, Republic of Indonesia, spatial data of Kungkai Watershed from Badan Pengelolaan DAS Ketahun, Bengkulu, Ministry of Forestry, Republic of Indonesia.

\section{RESULT AND DISCUSSIONS}

Kungkai watershed plays some functions involving Bukit Daun and Bukit Sanggul as forest protected areas for water recharge, forest conservation for wildlife hunting area of Semidang Bukit Kabo, enclave (agriculture land) surrounding 
wildlife hunting area, and agriculture cultivation area for traditional villagers.

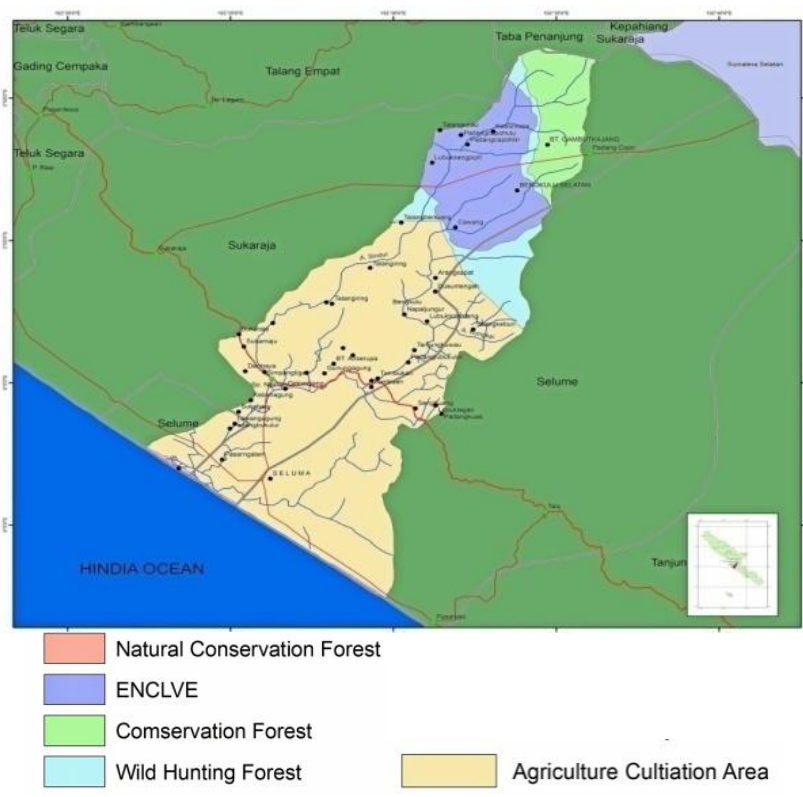

Fig. 1 b). Watershed lies on Bengkulu Province, Sumatera, Indonesia.

Level of degraded land condition on Kungkai watershed are more widespread, not only on traditional agriculture area, but also encroach to forest Conservation of wildlife hunting area Semidang Bukit Kabu and forest protected area of Bukit Daun and Bukit Sanggul. Based on degraded land conditions published options for land conservation and management practices based on land functions was shown in Table II.

On forest protected areas of Bukit Daun and Bukit Sanggul have opportunities for social forestry development through empowerment of surrounding villagers as wide of 2.629.62 $\mathrm{Ha}$, or $7.95 \%$ of the Kungkai. Increasing productivity of the forest by planting multi purposes tree species such as rubber, candle nuts, durian, and other plant products without logging.

Options for land management practices on forest conservation area of Semidang Bukit Kabu wildlife hunting area was shown on Table III.

Options for land management practices based on land functions of forest conservation of Semidang Bukit Kabu wildlife hunting area is re-forestation and re-vegetation with local seed and young trees species.

Agriculture cultivation area occupied by traditional villagers and enclave surrounding by forest of wildlife hunting area are categorized as degraded to poor degraded conditions. The degraded and poorer reached a wide of $28,172 \mathrm{Ha}$, or $47 \%$ of agriculture area, or $40 \%$ of the Kungkai watershed. The degraded agriculture land should be cultivated with environmental friendly, for the long run improving land productivities and sustainable agriculture. Options for land management practices on agriculture area involve planting cover crops with minimum tillage, with credit terrace, till applied bench terraces. Options for land management practices on the agriculture areas was shown on Table IV.

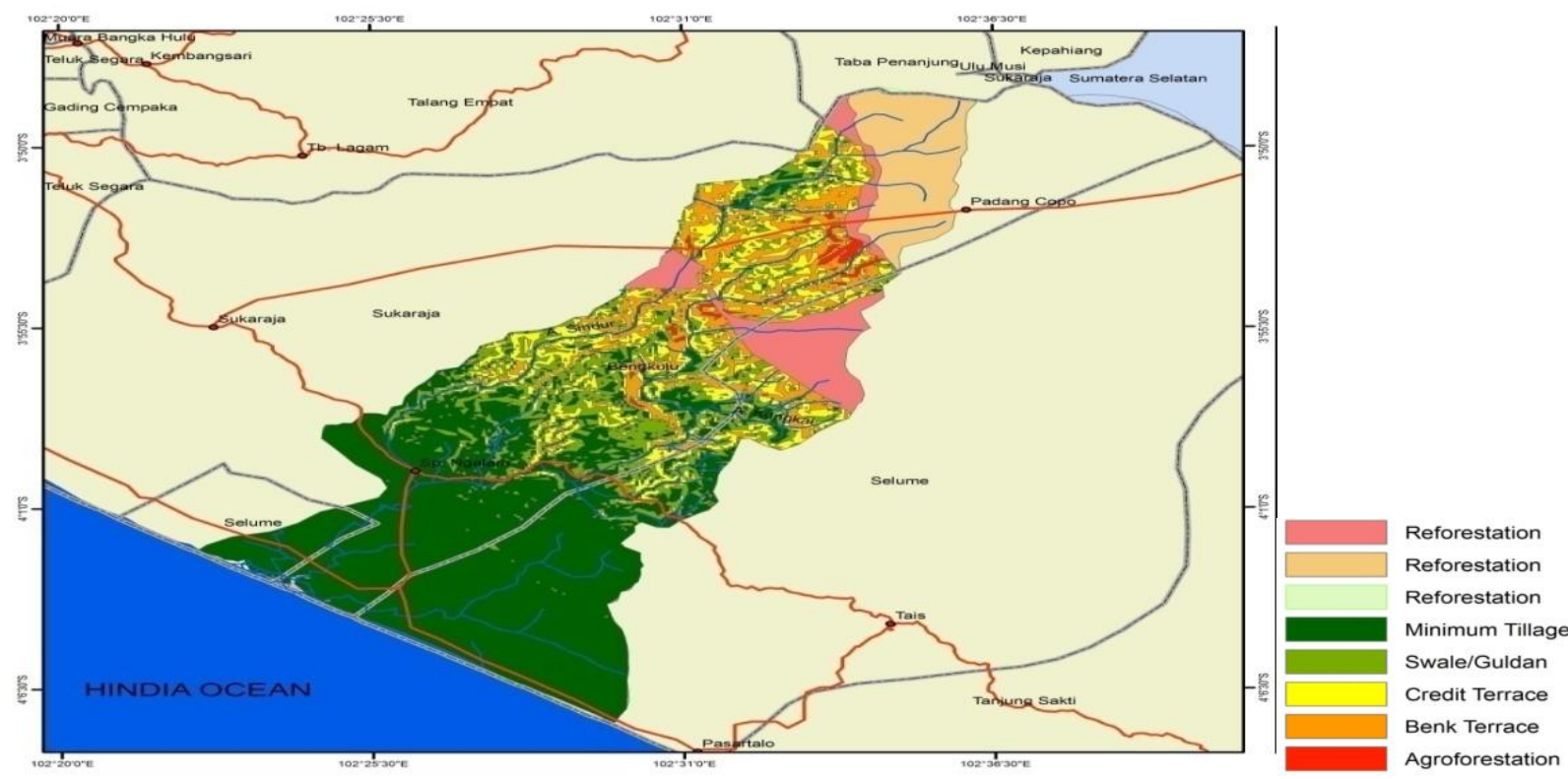

Fig. 2. Distribution of options for land conservation and management practices on Kungkai Watershed, Bengkulu, Sumatera, Indonesia.

Options for land conservation land management practices based on land uses and functions on Kungkai watershed, Bengkulu, Sumatera, Indonesia was depicted in Fig. 3.

\section{CONCLUSIONS}

Forest Protection Areas of Bukit Daun and Bukit Sanggul which wide 2,629.62 Ha, or 7.95\% of the Kungkai watershed, only on small area was categorized degraded level on environmental values. These protections areas could be developed as social forestry through empowerment societies surrounding the forest, and planting multi-purposes tree species.

Forest Conservation of Semidang Bukit Kabu Wildlife Hunting Area which wide 2,275.35 Ha, or $6.88 \%$ of Kungkai watershed mostly was categorized slightly degraded to degraded level of environmental values. Options for land conservation and management practices re-forestation and re-vegetation with local seed and young plant species. Agricultural and social activities within the wildlife hunting 
area must be sent out this area.

The degraded agriculture land should be cultivated with environmental friendly, for the long run improving land productivities and sustainable agriculture. Options for land management practices on agriculture area involve planting cover crops with minimum tillage, with credit terrace, till applied bench terraces.

\section{REFERENCES}

[1] I. W. Susanto. (2012). Konservasi Wilayah Daerah Aliran Sungai (DAS) guna Mendukung Pembangunan Wilayah DAS Berkelanjutan. [Online]. Available: http://wayansusantoshut.blogspot.com/2012/02

[2] I. G. Tunas, "Prediksi erosi lahan DAS bengkulu dengan sistem informasi geografis (SIG)," Jurnal Smartek, vol. 3, no. 3 .

[3] D. I. D Arini, L. B. Prasetyo, and O. Rusdiana, "Aplikasi sistem informasi geografis (sig) dan penginderaan jauh untuk model hidrologi answers dalam memprediksi erosi dan sedimentasi. studi kasus dta cipokokol sub das cisadane hulu, kabupaten bogor," Media Konservasi, vol. 12, no. 2, 2007.

[4] S. Nurmuin et al., "Barchia. Penentuan tingkat bahaya erosi das padang guci melalui citra TM," May 9, 2012.

[5] K. Amri, A. Halim, Ngudiantoro, and M. F. Barchia, "Rainfall analysis for estimation of peak discharge and soil erosion on the catchment area of musi hydro-power plant," Bengkulu Indonesia, Hongkong, 2014.

[6] A. Farianto and K. Amri, "Rainfall analysis for prediction of peak debit and its effect on sub-basin sedimentation on Lemau, Central Bengkulu," Teknosia, vol. II, no. 10, 2012.
[7] Siharto, K. Amri, and M. F. Barchia, "Analisis erosi dan tingkat kekritisan lahan pada das kungkai kabupaten seluma," Thesis, Departement of Civil Engineering. Faculty of Engineering, University of Bengkulu, Indonesia, 2012.

[8] Director General of Watersheed Management and Social Forestry, Minister of Forestry, Republic of Indonesia, Jakarta, 2004.

[9] Djaenuddin et al., "Kesesuaian Lahan untuk Tanaman Pertanian dan Tanaman Kehutanan," Laporan Teknis No. 7 versi 1.0 Centre for Soil and Agriclimate Research,. Bogor, 1994.

[10] Purwowidodo, "Konservasi tanah di kawasan hutan," Institut Pertanian Bogor Press, Bogor, 1999.

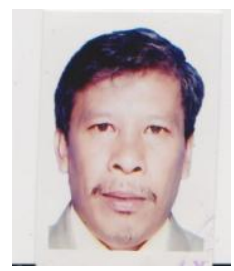

Muhammad Faiz Barchia was born in Sritanjung, South Sumatera, Indonesia, on November 20, 1959 $\mathrm{He}$ received his undergraduated degree in soil science from Faculty of Agriculture, Sriwijaya University, Palembang, Indonesia, 1985, and the master degree in soil science from Faculty of Agriculture, University of Sydney, Australia, 1995, and the doctor degree in soil science from Faculty of Agriculture, Bogor Agriculture University, Bogor, Indonesia, 2002.

He worked as a lecturer at Faculty of Agriculture, University of Bengkulu, Indonesia since 1986 until now. And he published some books.

His research interests are focused on soil amendment for agricultural and land conservation for foresty. Dr. Barchia involves as a member of Indonesia Soil Science Society, and member of Indonesia Peat Society. 